\title{
Hydrogen Sulfide Alleviates Kiwifruit Ripening and Senescence by Antagonizing Effect of Ethylene
}

\author{
Ting-Ting $\mathrm{Li}^{1}$, Zhi-Rong $\mathrm{Li}^{1}$, Kang-Di Hu${ }^{1}$, Lan-Ying Hu, \\ Xiao-Yan Chen, and Yan-Hong Li \\ School of Food Science and Engineering, Hefei University of Technology, \\ Hefei 230009, China
}

\author{
Ying Yang \\ College of Environment and Energy Engineering, Anhui Jianzhu University, \\ Hefei 203601, China
}

Feng Yang

Xuzhou Institute of Agricultural Sciences, Xuhuai District of Jiangsu

Province, Xuzhou 221131, China

\author{
Hua Zhang ${ }^{2}$ \\ School of Food Science and Engineering, Hefei University of Technology, \\ Hefei 230009, China
}

Additional index words. antioxidative enzymes, ethylene synthesis pathway, fruit softening, reactive oxygen species

\begin{abstract}
Kiwifruit (Actinidia deliciosa) is a typical climacteric fruit, and its ripening is closely associated with ethylene. In this study, we present evidence that $\mathrm{H}_{2} \mathrm{~S}$ alleviated ethylene-induced ripening and senescence of kiwifruit. Kiwifruit were fumigated with ethylene released from $0.4 \mathrm{~g} \cdot \mathrm{L}^{-1}$ ethephon solution or $\mathrm{H}_{2} \mathrm{~S}$ with 1 mm sodium hydrosulfide (NaHS) as the donor or in combination. Fumigation with ethylene was found to accelerate kiwifruit ripening and $\mathrm{H}_{2} \mathrm{~S}$ treatment effectively alleviated ethylene-induced fruit softening in parallel with attenuated activity of polygalacturonase (PG) and amylase. Ethylene $+\mathrm{H}_{2} \mathrm{~S}$ treatment also maintained higher levels of ascorbic acid, titratable acid, starch, soluble protein, and reducing sugar compared with ethylene group, whereas suppressed the increase in chlorophyll and carotenoid. Kiwifruit ripening and senescence under ethylene treatment was accompanied by elevation in reactive oxygen species (ROS) levels, including $\mathrm{H}_{2} \mathrm{O}_{2}$ and superoxide anion and malondialdehyde (MDA), but combined treatment of ethylene plus $\mathrm{H}_{2} \mathrm{~S}$ alleviated oxidative stress in fruit. Furthermore, the activities of antioxidative enzymes catalase (CAT) and ascorbate peroxidase (APX) were increased by ethylene $+\mathrm{H}_{2} \mathrm{~S}$ treatment in comparison with ethylene alone, whereas the activities of lipoxygenase (LOX) and polyphenol oxidase (PPO) were attenuated by $\mathrm{H}_{2} \mathrm{~S}$ treatment. Further investigations showed that $\mathrm{H}_{2} \mathrm{~S}$ repressed the expression of ethylene synthesis-related genes $A d S A M$, $A d A C S 1, A d A C S 2, A d A C O 2$, and $A d A C O 3$ and cysteine protease genes, such as $A d C P 1$ and $A d C P 3$. Taken together, our findings suggest that $\mathrm{H}_{2} \mathrm{~S}$ alleviates kiwifruit ripening and senescence by antagonizing the effect of ethylene through reduction of oxidative stress and inhibition of ethylene synthesis pathway.
\end{abstract}

Fruits are consumed by people for food, either as edible products, for culinary ingredients, or for medicinal use for a long time. They are genetically a very diverse

Received for publication 13 July 2017. Accepted for publication 29 Sept. 2017

Funding for this work was provided by the National Natural Science Foundation of China (31670278, 31470013, 31300133), the earmarked fund for China Agriculture Research System CARS-10-B1, Anhui Provincial Science and Technology Major Project (6030701073) and Anhui Provincial Education Department (KJ2015ZD12).

${ }^{1}$ These authors contributed equally to this work ${ }^{2}$ Corresponding author. E-mail: hzhanglab@hfut. edu.cn. low concentrations $\left(0.1 \mu \mathrm{L} \cdot \mathrm{L}^{-1}\right)$ can stimulate fruit ripening and softening (Harman and McDonald, 1989; Yin et al., 2008). Postharvest fruit ripening and senescence result in profound changes in fruit sensory, texture, and nutritional quality because of cell wall degradation, membrane deterioration, cell structure modification, and cell death (Kumar et al., 2016). Thus, development of new storage protocols for kiwifruit to delay fruit softening as well as to ensure good texture and nutrients is of commercial importance for producers.

Ethylene or ethephon (2-chloroethyl phosphoric acid) is applied commercially to accelerate the ripening of climacteric fruit (Korsak and Park, 2010). Ethylene biosynthesis has been clarified in plant, which involves the conversion of methionine to S-adenosyl methionine (SAM) by SAM synthetase, SAM to 1-aminocyclopropane-1carboxylic acid (ACC) catalyzed by ACC synthase (ACS), and ACC to ethylene catalyzed by ACC oxidase (ACO) (Adams and Yang, 1979; Mworia et al., 2010). Besides ethylene, ROS and oxidative stress are also responsible for fruit senescence (Tian et al., 2013). ROS is highly reactive and causes oxidative damage to plant cells (Apel and Hirt, 2004), including protein breakdown and lipid peroxidation. Therefore, developing strategies to attenuate ethylene synthesis and inhibit ROS production or promote ROS metabolism could be effective for reducing quality deterioration and extending the storage life of kiwifruit.

Hydrogen sulfide $\left(\mathrm{H}_{2} \mathrm{~S}\right)$ is emerging as a new gaseous signaling molecule in diverse organisms, such as bacteria, fungi, worms, human, and plants (Wang, 2012). $\mathrm{H}_{2} \mathrm{~S}$ participates in multiple processes in plants, including seed germination, stomatal movement, root organogenesis, and photosynthesis (García-Mata and Lamattina, 2010; Jin et al., 2013; Zhang et al., 2009). Furthermore, evidence indicates that $\mathrm{H}_{2} \mathrm{~S}$ can prolong postharvest shelf life of many fruits and vegetables, including strawberry, kiwifruit, and broccoli by regulating ROS metabolism, antioxidant system, and senescence-related genes expression (Gao et al., 2013; Hu et al., 2012; Li et al., 2014, 2017; Zhu et al., 2014). Moreover, our previous data showed that ethylene synthesis genes, such as BoACS2 and $B o A C S 3$, were downregulated by $\mathrm{H}_{2} \mathrm{~S}$ in dark-induced senescence of broccoli (Brassica oleracea $\mathrm{L}$.) ( $\mathrm{Li}$ et al., 2015). However, there is still a lack of information about the molecular interaction between $\mathrm{H}_{2} \mathrm{~S}$ and ethylene signaling in fruit ripening.

In the present study, ethylene (released by ethephon), $\mathrm{H}_{2} \mathrm{~S}$ or in combination was applied to kiwifruit, and the effects of $\mathrm{H}_{2} \mathrm{~S}$ signal on fruit softening, ROS metabolism, and ethylene synthesis were investigated. The results confirmed the regulatory role of $\mathrm{H}_{2} \mathrm{~S}$ in ethylenepromoted kiwifruit ripening and senescence.

\section{Materials and Methods} cerned about its appearance and textual quality. As a typical climacteric fruit, kiwifruit postharvest ripening and senescence are very sensitive to ethylene, and even extremely
Plant materials and treatments. In this study, kiwifruit (A. deliciosa cv. Qinmei) 
were kindly supplied by the Anhui Academy of Agricultural Sciences, Hefei, Anhui province, China. The fruit were harvested in the same day with similar size and maturity $(80 \%)$ and sorted without physical damages or infections. Kiwifruit were fumigated with different concentrations $(0,0.4,0.6$, and $0.8 \mathrm{~g} \cdot \mathrm{L}^{-1}$ ) of ethephon solutions (in $50 \mathrm{~mm}$ phosphate saline buffer, $\mathrm{pH}$ 7.0) for $8 \mathrm{~d}$, and the concentration of $0.4 \mathrm{~g} \cdot \mathrm{L}^{-1}$ was selected for the following experiments. Kiwifruit were divided into four groups with 15 kiwifruit for each group. The first group, i.e., the control group which includes five kiwifruit in three replicates was stored in sealed containers (volume $3 \mathrm{~L}$ ) at $25^{\circ} \mathrm{C}$ with a relative humidity of $85 \%$ to $90 \%$. The second group $\left(\mathrm{H}_{2} \mathrm{~S}\right.$ group $)$ in the container was fumigated with $\mathrm{H}_{2} \mathrm{~S}$ released from $150 \mathrm{~mL}$ of $1 \mathrm{~mm} \mathrm{NaHS}$. The third group (ethylene group abbreviated as ETH group) was fumigated with ethylene released from $100 \mathrm{~mL}$ of $0.4 \mathrm{~g} \cdot \mathrm{L}^{-1}$ ethephon solution. The fourth group (ETH $+\mathrm{H}_{2} \mathrm{~S}$ group) was stored in a container containing $150 \mathrm{~mL}$ of $1 \mathrm{~mm} \mathrm{NaHS}$ and $100 \mathrm{~mL}$ of $0.4 \mathrm{~g} \cdot \mathrm{L}^{-1}$ ethephon solution which were stored in two separate beakers. NaHS and ethephon solutions were renewed daily, and fruit flesh (without peel and seeds) was sampled at different time points for assays.

Determination of fruit firmness. Fruit firmness was measured at the equatorial part of each intact kiwifruit by a 2-mm diameter flat probe with a texture analyzer (Model TA-XT plus; Stable Micro System, England, UK). The penetration depth was $15 \mathrm{~mm}$, and the cross-head speed was $1.5 \mathrm{~mm} \cdot \mathrm{s}^{-1}$. When the probe was penetrating the fruit, the firmness of the peel and flesh was obtained sequentially. Fruit firmness values were an average of eight replicates \pm standard deviation (SD).

Determination of the activities of $P G$ and amylase. Polygalacturonase (PG) (EC 3.2.1.15) activity was determined according to Pathak and Sanwal (1998), and 1 unit (U) of activity was defined as $1 \mu \mathrm{mol}$ galacturonic acid generated per $1 \mathrm{~g}$ fresh weight (FW) per hour. Amylase activity in kiwifruit samples $(5.00 \pm 0.05 \mathrm{~g})$ was determined using the starch-iodine method according to Collins et al. (1972). One unit of activity was calculated by taking the quantity of the enzyme to reach $50 \%$ of the original color intensity.

Analysis of chlorophyll, carotenoid, ascorbic acid, titratable acidity (TA), starch, soluble protein, and reducing sugar in kiwifruit. The contents of chlorophyll and carotenoid in kiwifruit were determined in accordance with the methods of Lichtenthaler and Wellburn (1983) and Nath et al. (2011), respectively. $5.0 \pm 0.5 \mathrm{~g}$ of kiwifruit flesh were sampled. Each analysis was repeated three times, and the results of chlorophyll and carotenoid were expressed as mg.g ${ }^{-1} \mathrm{FW}$.

Ascorbic acid content was determined by the 2,6-dichloroindophenol titrimetric method in accordance with the Association of Official Analytical Chemists method (AOAC, 1984). The assay was repeated in triplicate, and the results were expressed as $\mathrm{mg} \cdot \mathrm{g}^{-1} \mathrm{FW}$.
The TA of kiwifruit juice was determined by titration with $0.1 \mathrm{M} \mathrm{NaOH}$ to $\mathrm{pH}$ 8.1 (Jin et al., 2014), and the TA value was expressed as percent of citric acid in kiwifruit juice.

For the determination of starch content in kiwifruit, fruit tissue $(5.00 \pm 0.05 \mathrm{~g})$ was ground in a cooled mortar with $4 \mathrm{~mL}$ of $80 \%$ $\mathrm{Ca}\left(\mathrm{NO}_{3}\right)_{2}$, and the homogenate was centrifuged at $12,000 \mathrm{~g}$ for $15 \mathrm{~min}$. The supernatant was discarded and the pellet washed twice with $5 \mathrm{~mL}$ of sterile water. Starch content was determined by following the method described by Sanz et al. (1987).

For the determination of reducing sugar and soluble protein, fruit samples $(5.00 \pm$ $0.05 \mathrm{~g}$ ) were ground with $2 \mathrm{~mL}$ of $200 \mathrm{~mm}$ phosphate buffer ( $\mathrm{pH} 7.0$ ) containing $0.15 \mathrm{M}$ $\mathrm{NaCl}$. Then, the homogenate was centrifuged at $12,000 \mathrm{~g}$ for $30 \mathrm{~min}$ at $4{ }^{\circ} \mathrm{C}$. Reducing sugar was measured by the method of dinitrosalicylic acid according to Miller (1959). The supernatant $(0.2 \mathrm{~mL})$ was mixed with $1.5 \mathrm{~mL}$ of 3,5-dinitrosalicylic acid and $1.8 \mathrm{~mL}$ of $\mathrm{dH}_{2} \mathrm{O}$, then the mixture was heated at $100{ }^{\circ} \mathrm{C}$ for $5 \mathrm{~min}$ and cooled immediately. After adding $25 \mathrm{~mL}$ of $\mathrm{dH}_{2} \mathrm{O}$ to the mixture, the content of reducing sugar was determined at $540 \mathrm{~nm}$ by using a spectrophotometer. Coomassie brilliant blue was used to determine the content of soluble protein. Absorbance was recorded at $595 \mathrm{~nm}$ by the method of Bradford (1976). The calibration curves were prepared by using glucose and bovine serum albumin as the standard, respectively. The contents of reducing sugar and soluble protein were expressed as $\mathrm{mg} \cdot \mathrm{g}^{-1} \mathrm{FW}$.

Determination of hydrogen peroxide $\left(\mathrm{H}_{2} \mathrm{O}_{2}\right)$, superoxide anion $\left(\cdot \mathrm{O}_{2}^{-}\right)$, and $M D A$. For the determination of $\mathrm{H}_{2} \mathrm{O}_{2}$, fresh kiwifruit flesh samples $(5.00 \pm 0.05 \mathrm{~g})$ were homogenized with $2 \mathrm{~mL}$ of chilled acetone and then centrifuged at $12,000 \mathrm{~g}$ for $30 \mathrm{~min}$ at $4{ }^{\circ} \mathrm{C}$ and $0.5 \mathrm{~mL}$ of the supernatant fraction was mixed with $1.5 \mathrm{~mL}$ of $\mathrm{CHCl}_{3}$ and $\mathrm{CCl}_{4}(1: 3, \mathrm{v} / \mathrm{v})$ mixture. After adding $2.5 \mathrm{~mL}$ of distilled water, the mixture was centrifuged at $12,000 \mathrm{~g}$ for $1 \mathrm{~min}$ and the aqueous phase collected for $\mathrm{H}_{2} \mathrm{O}_{2}$ determination (Zhang et al., 2011). $\mathrm{H}_{2} \mathrm{O}_{2}$ content was indicated as mmol. $\mathrm{g}^{-1} \mathrm{FW}$.

The generation rate of $\cdot \mathrm{O}_{2}^{-}$was determined using hydroxylamine method (Elstner and Heupel, 1976). Fresh kiwifruit flesh samples $(5.00 \pm 0.05 \mathrm{~g})$ were ground with $3 \mathrm{~mL}$ of $50 \mathrm{~mm}$ Tris-HCl buffer $(\mathrm{pH} \mathrm{7.8)}$, and the homogenate was centrifuged at $12,000 \mathrm{~g}$ at $4{ }^{\circ} \mathrm{C}$ for $30 \mathrm{~min}$. The reaction mixture $(0.5 \mathrm{~mL})$ contained $50 \mathrm{~mm}$ Tris-HCl buffer ( $\mathrm{pH} 7.5), 0.5 \mathrm{~mm}$ XTT [sodium, 3-1-(phenylamino-carbonyl)-3, 4-tetrazoliumbis (4-methoxy-6-nitro), and benzenesulfonic acid hydrate], and $50 \mu \mathrm{L}$ of sample extracts. Corrections were made for the background absorbance in the presence of $50 \mathrm{U}$ of superoxide dismutase. The value of $\cdot \mathrm{O}_{2}^{-}$generation rate was expressed as $\mu \mathrm{g} \cdot \mathrm{g}^{-1} \cdot \mathrm{min}^{-1} \mathrm{FW}$.

MDA content was analyzed by following the method of Zhang et al. (2011). Kiwifruit flesh samples $(5.00 \pm 0.05 \mathrm{~g})$ were ground in liquid nitrogen and extracted in $3 \mathrm{~mL}$ of $0.1 \%$ trichloroacetic acid. An extinction coefficient of $155 \cdot \mathrm{mm}^{-1} \cdot \mathrm{cm}^{-1}$ was used to calculate MDA content and the value was expressed as $\mu \mathrm{mol} \cdot \mathrm{g}^{-1} \mathrm{FW}$.

Activity assay of CAT, APX, and guaiacol peroxidase (POD). Flesh tissue of kiwifruit $(5.0 \pm 0.05 \mathrm{~g})$ was ground in liquid nitrogen and homogenized with $3 \mathrm{~mL} 0.2 \mathrm{M}$ phosphate buffer ( $\mathrm{pH}$ 7.5) supplemented with $1 \mathrm{~mm}$ ethylene diamine tetraacetic acid, $1 \mathrm{~mm}$ phenylmethylsulfonyl fluoride, $5 \%$ polyvinyl pyrrolidone and $1 \mathrm{~mm}$ dithiothreitol. The homogenate was centrifuged for $30 \mathrm{~min}$ at $12,000 \mathrm{~g}$ at $4{ }^{\circ} \mathrm{C}$, and the supernatant was collected for enzyme activity analysis. The activity of CAT (EC 1.11.1.6) was measured based on the decrease in $\mathrm{H}_{2} \mathrm{O}_{2}$ concentration (Havir and McHale, 1987). APX (EC 1.11.1.11) activity was determined spectrometrically by the method of Nakano and Asada (1981). POD (EC 1.11.1.7) activity was determined based on the method of Zhang et al. (2008).

Analysis of activities of $L O X$ and PPO. For LOX (EC 1.13.11.12), kiwifruit flesh samples $(5.00 \pm 0.05 \mathrm{~g})$ were homogenized with $5 \mathrm{~mL}$ of $200 \mathrm{~mm}$ phosphate buffer ( $\mathrm{pH}$ 6.0) (Hu et al., 2012). The homogenate was centrifuged at $12,000 \mathrm{~g}$ at $4{ }^{\circ} \mathrm{C}$ for $10 \mathrm{~min}$, and $50 \mu \mathrm{L}$ of the supernatant enzyme extract was assayed in a mixture of $3 \mathrm{~mL}$ containing $200 \mathrm{~mm}$ borate buffer ( $\mathrm{pH} 6.0$ ), $0.25 \%$ linoleic acid and $0.25 \%$ Tween-20. The reaction was carried out at $25{ }^{\circ} \mathrm{C}$ for $5 \mathrm{~min}$, and the activity of LOX was determined by monitoring the changes in absorbance at $234 \mathrm{~nm}$.

Activity of PPO (EC 1.10.3.1) was assayed based on the method by Benjamin and Montgomery (1973). Kiwifruit samples $(5.00 \pm 0.05 \mathrm{~g})$ were homogenized with 3.0 $\mathrm{mL}$ of sodium phosphate buffer $(50 \mathrm{mM}, \mathrm{pH}$ 6.8). After centrifugation, PPO activity in supernatant was assayed with catechol as substrate. One unit of PPO activity was defined as an increase in 0.01 optical density (OD) value in absorbance at $410 \mathrm{~nm} \cdot \mathrm{min}^{-1}$. The results were expressed on a FW basis as $\mathrm{U}^{-\mathrm{g}^{-1}}$.

$R N A$ extraction and semiquantitative polymerase chain reaction (PCR) analysis. Total RNA was extracted from $0.15 \mathrm{~g}$ flesh tissue of kiwifruit samples using TransZol Plant kit (TransGene, Beijing, China). Firststrand cDNA was synthesized using a reverse transcription kit (Prime Script ${ }^{\mathrm{TM}}$ RT Master Mix; Takara, Tokyo, Japan) from $2.5 \mu \mathrm{g}$ total RNA. cDNA fragments were amplified by reversed transcript PCR (RT-PCR) with Prime Script RT Master Mix (TaKaRa, Tokyo, Japan). Primers used for RT-PCR are shown in Table 1. The expression of actin gene $A d A C T$ was used as a control. PCR conditions were initially denatured at $94{ }^{\circ} \mathrm{C}$ for $5 \mathrm{~min}$, followed by appropriate cycles of $94{ }^{\circ} \mathrm{C}$ for $30 \mathrm{~s}, 52{ }^{\circ} \mathrm{C}$ for $30 \mathrm{~s}$, and $72{ }^{\circ} \mathrm{C}$ for $30 \mathrm{~s}$. Then, the products of PCR underwent electrophoresis in $1 \%$ agarose.

Statistical analysis. The data in the article are based on three replicates in each experiment, and the experiments were repeated independently for three times. Statistical significance was tested by one-way analysis of variance using IBM SPSS Statistics (SPSS version 20.0; Armonk, NY), and the results 
Table 1. Primers used in reverse transcription-polymerase chain reaction.

\begin{tabular}{|c|c|c|c|}
\hline Gene name & Forward primer $\left(5^{\prime} \rightarrow 3^{\prime}\right)$ & Reverse primer $\left(5^{\prime} \rightarrow 3^{\prime}\right)$ & Accession number \\
\hline AdACS1 & СТCCTGCTCACGTTCATCAC & TGGAGTGGCTACTGTCCTTTA & AB007449 \\
\hline AdACS2 & TCAGATTCACCAATGACAAAAA & GTACGAGTAAACTATACCGACCC & AB005722 \\
\hline AdACO1 & GCATCATCCTCCTCTTCCA & TGACATTCTGTTGCCATCC & AB003514 \\
\hline AdACO2 & AAGAAGGCTTTCAGTGGC & GTGTTTCATTGGCGGGAC & HQ293205 \\
\hline $\mathrm{AdACO} 3$ & GATGTCCCGCCAATGAAA & GCCATCCGTCTGAGCAAT & HQ293207 \\
\hline$A d C P 3$ & GGAATGTTTGCGGAGTTG & CTGGCTTGGGAGTATTATCTG & EF530143 \\
\hline AdCP4 & TTCCTCTGCTTCGCCTTC & TGGTGAGCCACTTCTCGTAA & EF530144 \\
\hline AdCP5 & GATTGGAGGAAGTATGGGATT & CGTTGGCTAAGGCATTTATT & EF530145 \\
\hline AdCP6 & АTTCCTCCAGATCCTTCACC & ACATCGCCATCACTTCGTC & EF530146 \\
\hline
\end{tabular}
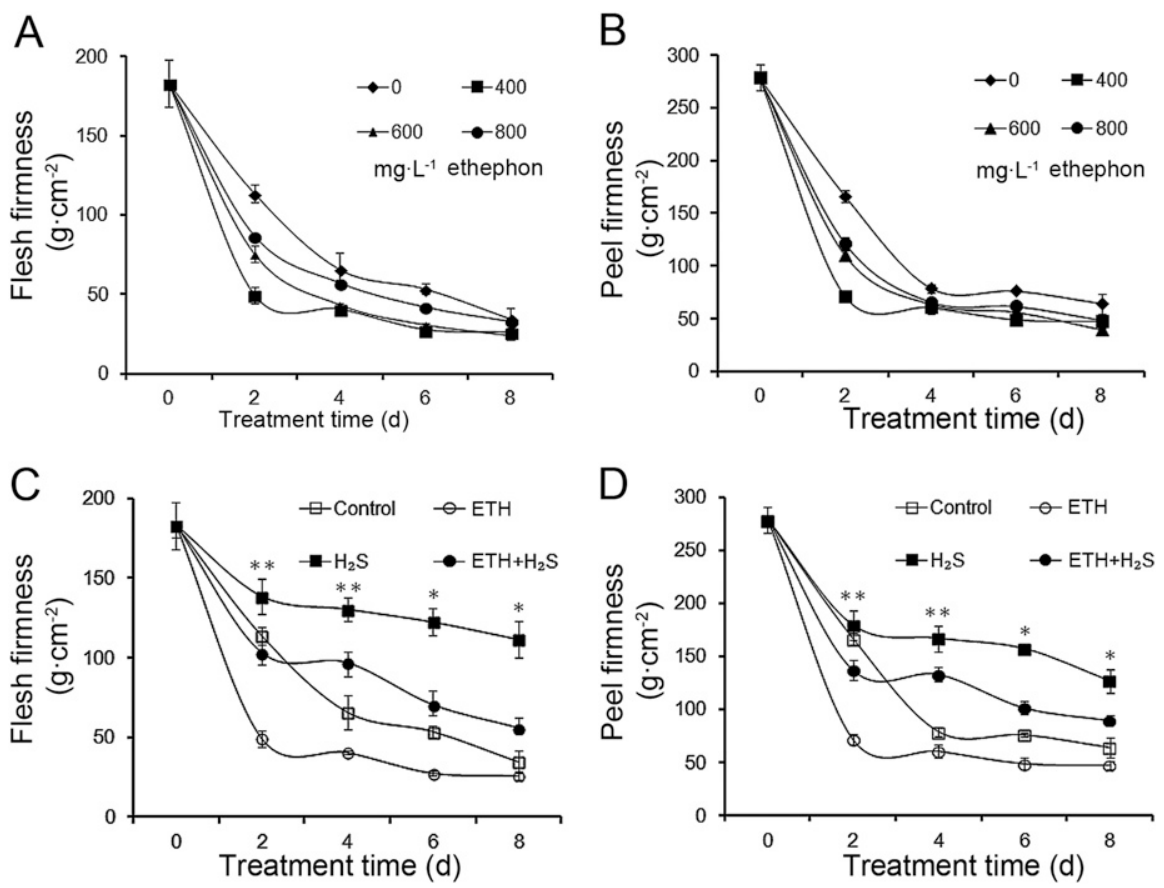

Fig. 1. Effects of ethylene and $\mathrm{H}_{2} \mathrm{~S}$ on flesh and peel firmness of kiwifruit. Kiwifruit were fumigated with different concentrations $\left(0,400,600\right.$, and $\left.800 \mathrm{mg} \cdot \mathrm{L}^{-1}\right)$ of ethephon aqueous solutions at $25^{\circ} \mathrm{C}$, and the firmness of flesh (A) and peel (B) was determined on Days 0, 2, 4, 6, and 8. Kiwifruits were then treated with ethylene, $\mathrm{H}_{2} \mathrm{~S}$ or in combination and the firmness of flesh (C) and peel (D) was determined on Days 0, 2, 4, 6, and 8. Control: $\mathrm{H}_{2} \mathrm{O} ; \mathrm{H}_{2} \mathrm{~S}: 1 \mathrm{~mm} \mathrm{NaHS}$; ETH: $0.4 \mathrm{~g} \cdot \mathrm{L}^{-1}$ ethephon solution; ETH $+\mathrm{H}_{2} \mathrm{~S}$ : $0.4 \mathrm{~g} \cdot \mathrm{L}^{-1}$ ethephon solution plus $1 \mathrm{~mm}$ NaHS. Data are presented as means \pm standard deviation $(n=8)$. The symbols * and ** stand for significant difference between ETH and ETH $+\mathrm{H}_{2} \mathrm{~S}$ at $P<0.05$ and $P<0.01$, respectively.
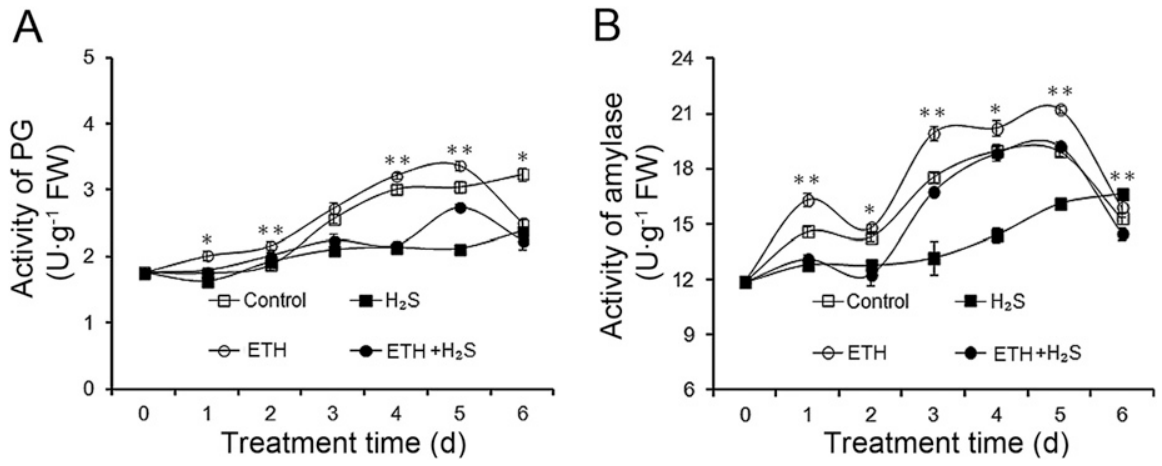

Fig. 2. Effects of ethylene, $\mathrm{H}_{2} \mathrm{~S}$ and combined treatment on the activities of polygalacturonase (PG) (A) and amylase (B) in kiwifruit. The activities were determined daily on Days 0 to 6 in kiwifruit treated with water, ethylene, $\mathrm{H}_{2} \mathrm{~S}$, or in combination at $25^{\circ} \mathrm{C}$. Control: $\mathrm{H}_{2} \mathrm{O} ; \mathrm{H}_{2} \mathrm{~S}: 1 \mathrm{~mm} \mathrm{NaHS}$; ETH: $0.4 \mathrm{~g} \cdot \mathrm{L}^{-1}$ ethephon solution; ETH $+\mathrm{H}_{2} \mathrm{~S}: 0.4 \mathrm{~g} \cdot \mathrm{L}^{-1}$ ethephon solution plus $1 \mathrm{~mm}$ NaHS. Data are presented as means \pm standard deviation $(n=3)$. The symbols * and $* *$ stand for significant difference between ETH and $\mathrm{ETH}+\mathrm{H}_{2} \mathrm{~S}$ at $P<0.05$ and $P<0.01$, respectively. were expressed as the means \pm SD. The significant differences were calculated after a significance $(P<0.01$ or $P<0.05) t$ test.

\section{Results}

Effect of ethylene and $\mathrm{H}_{2} \mathrm{~S}$ on kiwifruit softening. Kiwifruit were fumigated with different concentrations $(0,0.4,0.6$, and 0.8 $\mathrm{g} \cdot \mathrm{L}^{-1}$ ) of ethephon solutions and the firmness of the flesh and peel was determined (Fig. 1A and B). The firmness values of the flesh and peel decreased gradually in all ethephon treatments and control fruit. A significant decrease in firmness was observed in 0.4 $\mathrm{g} \cdot \mathrm{L}^{-1}$ ethephon treatment, suggesting that the ripening of kiwifruit was strongly stimulated by external application of $0.4 \mathrm{~g} \cdot \mathrm{L}^{-1}$ ethephon. To study the possible role of $\mathrm{H}_{2} \mathrm{~S}$ in ethylene-induced fruit ripening, $\mathrm{H}_{2} \mathrm{~S}$ released from $1 \mathrm{~mm}$ NaHS aqueous solutions was applied to kiwifruit alone or in combination with ethylene. Flesh and peel softening of kiwifruit was markedly accelerated by exogenous ethylene treatment especially during the first $2 \mathrm{~d}$ of storage, whereas was inhibited significantly by combined treatment of $\mathrm{H}_{2} \mathrm{~S}$ and ethylene (Fig. $1 \mathrm{C}$ and D). Besides, $\mathrm{H}_{2} \mathrm{~S}$ could maintain a higher value of flesh and peel firmness compared with control, ethylene, and $\mathrm{H}_{2} \mathrm{~S}$ +ethylene group. The results indicated that $\mathrm{H}_{2} \mathrm{~S}$ has an obvious effect in maintaining the firmness of flesh and peel when applied alone or in combination with ethylene.

Effects of ethylene and $\mathrm{H}_{2} \mathrm{~S}$, alone and in combination, on $P G$ and amylase activities. Then, the enzyme activities required for nutrient degradation and fruit softening were determined. PG activity in control and ethylene group rose continuously except a drop for ethylene group on Day 6 (Fig. 2A). By contrast, treatment with $\mathrm{H}_{2} \mathrm{~S}$ or ethylene + $\mathrm{H}_{2} \mathrm{~S}$ significantly prevented the increase in PG activity compared with control or ethylene treatment. Amylase activity increased gradually in control, ethylene, and ethylene + $\mathrm{H}_{2} \mathrm{~S}$, whereas the increase was attenuated in $\mathrm{H}_{2} \mathrm{~S}$ treatment (Fig. 2B). Besides, ethylene + $\mathrm{H}_{2} \mathrm{~S}$ maintained a significantly lower level of amylase activity compared with ethylene alone during the whole storage, suggesting that $\mathrm{H}_{2} \mathrm{~S}$ could alleviate starch degradation in kiwifruit by attenuating amylase activity. 
Effects of ethylene and $\mathrm{H}_{2} \mathrm{~S}$, alone and in combination, on contents of chlorophylls, carotenoid, ascorbic acid, TA, starch, soluble protein, and reducing sugar in kiwifruit. To test the effects of $\mathrm{H}_{2} \mathrm{~S}$ in delaying ethylene-induced ripening and senescence in kiwifruit, functional and nutritional components, including chlorophyll, carotenoid, ascorbic acid, starch, TA, soluble protein, and reducing sugar, were determined. The content of total chlorophyll increased gradually in all treatments during kiwifruit storage (Fig. 3A). However, chlorophyll content in ethylene-treated fruit was significantly higher than that of the control, $\mathrm{H}_{2} \mathrm{~S}$ and ethylene $+\mathrm{H}_{2} \mathrm{~S}$ groups after $2 \mathrm{~d}$ of storage. $\mathrm{H}_{2} \mathrm{~S}$ treatment alone maintained a significantly lower level of chlorophyll than other three groups since $3 \mathrm{~d}$ of storage. The changes of chlorophyll $a$ and $b$ showed a similar change in pattern to that of total chlorophyll (Fig. 3B and C).
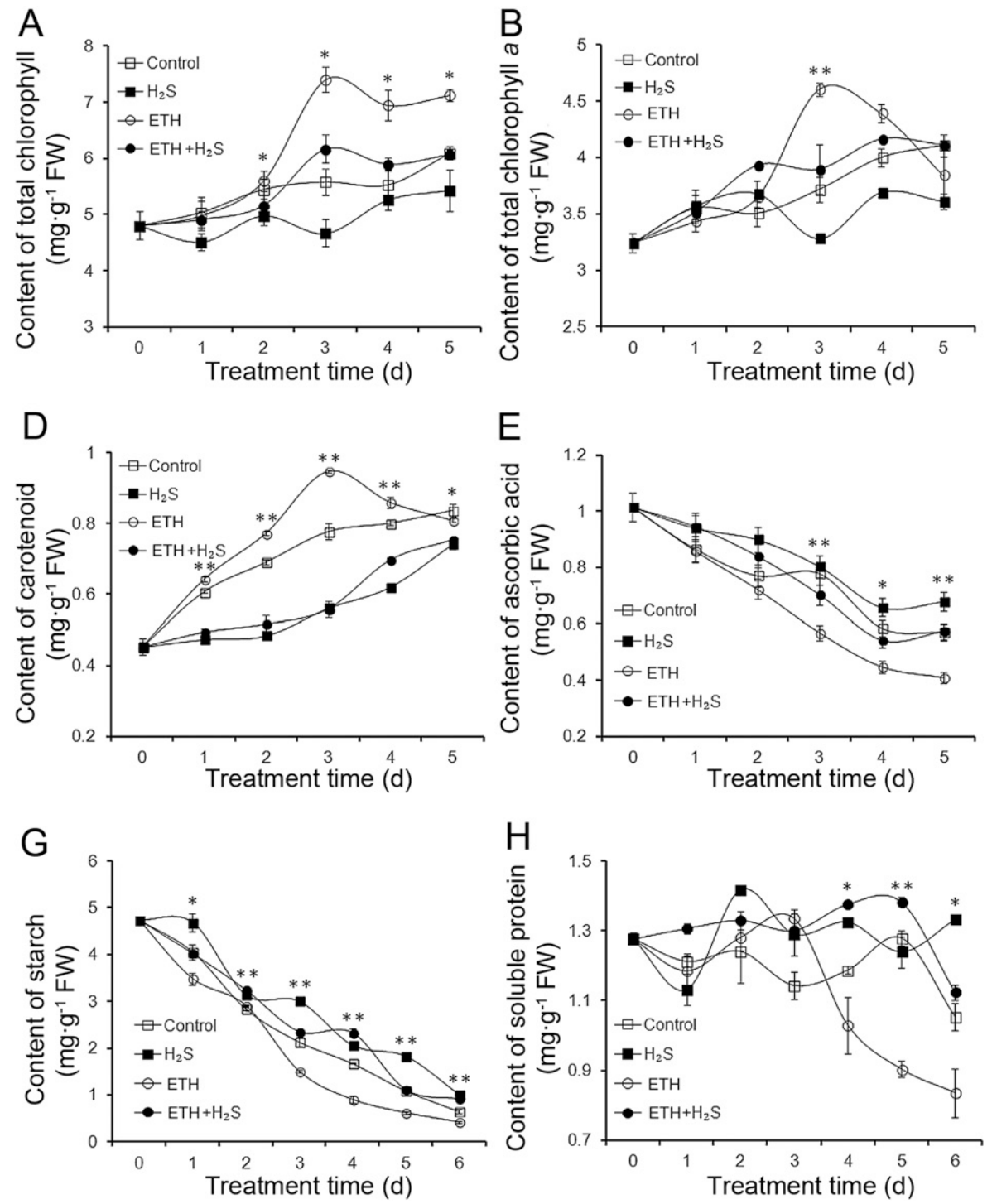

TA decreased progressively with storage time in all samples (Fig. 3F). Ethylene treatment induced a faster decrease in TA compared with other groups, whereas combined treatment of ethylene $+\mathrm{H}_{2} \mathrm{~S}$ alleviated the decrease especially on Days 2 and 5. Starch content in kiwifruit decreased continuously in all treatments (Fig. 3G). Starch was degradated faster in ethylene-treated group, whereas ethylene $+\mathrm{H}_{2} \mathrm{~S}$ treatment significantly counteracted the degradation.

Soluble protein content in control kiwifruit fluctuated during the first $5 \mathrm{~d}$ of storage followed by a decline on Day 6, whereas ethylene treatment triggered a dramatic decrease in soluble protein after $3 \mathrm{~d}$ of storage (Fig. $3 \mathrm{H}$ ). Ethylene $+\mathrm{H}_{2} \mathrm{~S}$ and $\mathrm{H}_{2} \mathrm{~S}$ treatment tended to sustain stable level of soluble protein except a decrease on Day 5 for ethylene + $\mathrm{H}_{2} \mathrm{~S}$ and the values were significantly higher than that of ethylene group on Days 4 to 6 (Fig. 3H). Reducing sugar content in the
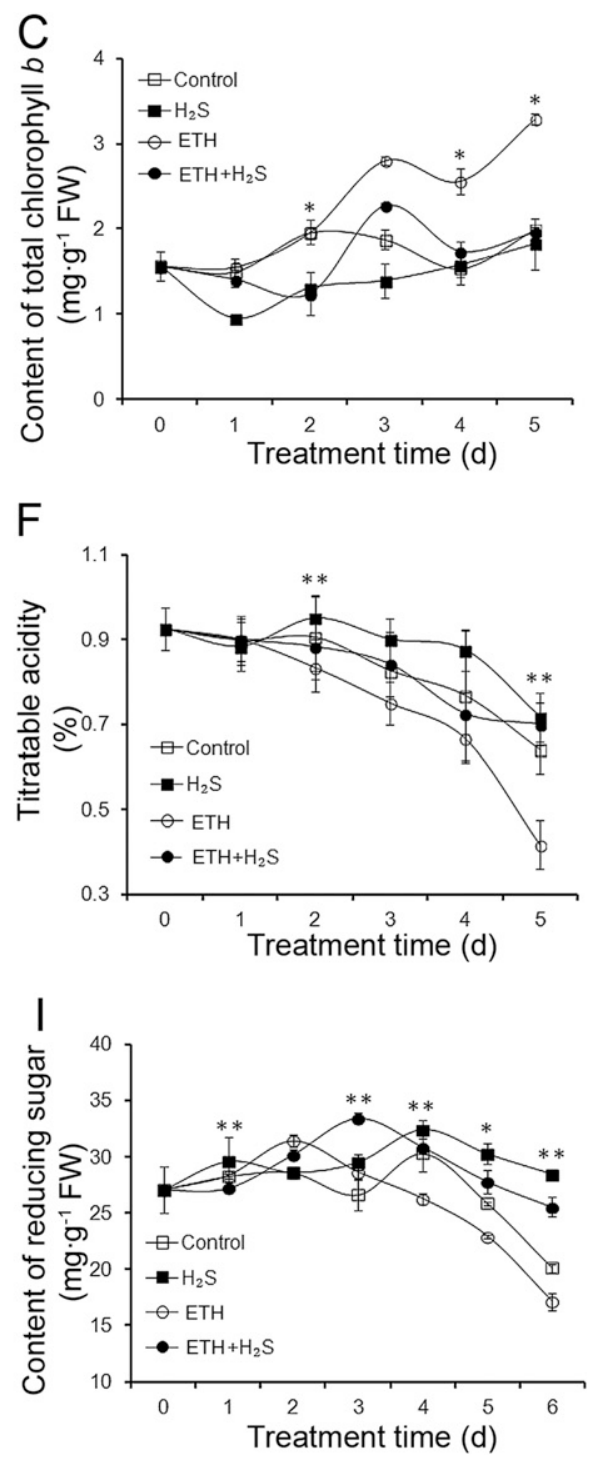

Fig. 3. Effects of ethylene, $\mathrm{H}_{2} \mathrm{~S}$, and combined treatment on the contents of total chlorophyll (A), chlorophyll $a$ (B), chlorophyll $b(\mathbf{C})$, carotenoid (D), ascorbic acid $(\mathbf{E})$, titratable acidity $(\mathbf{F})$, starch $(\mathbf{G})$, soluble protein $(\mathbf{H})$ and reducing sugar $(\mathbf{I})$ in kiwifruit. Kiwifruits were treated with water, ethylene, $\mathrm{H}_{2} \mathrm{~S}$, or in combination at $25^{\circ} \mathrm{C}$, and the data were determined on Days 0 to 5 or 6 . Control: $\mathrm{H}_{2} \mathrm{O} ; \mathrm{H}_{2} \mathrm{~S}: 1 \mathrm{~mm} \mathrm{NaHS}$; ETH: $0.4 \mathrm{~g} \cdot \mathrm{L}^{-1}$ ethephon solution; ETH $+\mathrm{H}_{2} \mathrm{~S}$ : $0.4 \mathrm{~g} \cdot \mathrm{L}^{-1}$ ethephon solution plus $1 \mathrm{~mm}$ NaHS. Data are presented as means \pm standard deviation $(n=3)$. The symbols * and ** stand for significant difference between $\mathrm{ETH}$ and $\mathrm{ETH}+\mathrm{H}_{2} \mathrm{~S}$ at $P<0.05$ and $P<0.01$, respectively. 
control kiwifruit fluctuated till Day 4 followed by a decrease, whereas ethylene induced a decrease after $2 \mathrm{~d}$ of storage (Fig. 3I). Ethylene $+\mathrm{H}_{2} \mathrm{~S}$ alleviated the reduction in reducing sugar and induced significant higher level since $3 \mathrm{~d}$ of treatment compared with ethylene group (Fig. 3I).

Effects of ethylene and $\mathrm{H}_{2} \mathrm{~S}$, alone and in combination, on contents of $\mathrm{H}_{2} \mathrm{O}_{2}$ and $M D A$, and $\cdot \mathrm{O}_{2}^{-}$production in kiwifruit. As ROS are involved in the senescence process of kiwifruit, levels of $\mathrm{H}_{2} \mathrm{O}_{2}$ and MDA, and production of. $\mathrm{O}_{2}^{-}$were determined. As indicated in Fig. 4A, $\mathrm{H}_{2} \mathrm{O}_{2}$ content increased gradually during storage time in all treatments. Ethylene treatment induced rapid accumulation of $\mathrm{H}_{2} \mathrm{O}_{2}$, whereas ethylene $+\mathrm{H}_{2} \mathrm{~S}$ suppressed the accumulation after $2 \mathrm{~d}$ of storage. Similarly, an increase in $\cdot \mathrm{O}_{2}^{-}$production was observed in all groups. The formation rate of $\cdot \mathrm{O}_{2}^{-}$increased rapidly in ethylene treatment, whereas ethylene $+\mathrm{H}_{2} \mathrm{~S}$ significantly alleviated the increase after $1 \mathrm{~d}$ of storage. In addition, $\mathrm{H}_{2} \mathrm{~S}$ treatment alone induced significantly less $\cdot \mathrm{O}_{2}^{-}$production compared with control after $3 \mathrm{~d}$ of treatment (Fig. 4B).

MDA, an indicator of lipid peroxidation, showed an consistent increase in all samples during the first $3 \mathrm{~d}$ of storage (Fig. 4C). In ethylene group, content of MDA increased dramatically and peaked on Day 3 followed by a decrease, whereas the increase was significantly attenuated by ethylene $+\mathrm{H}_{2} \mathrm{~S}$ treatment. On Days 2 and 3, MDA content in ethylene sample was about 2- and 3-fold of that in ethylene $+\mathrm{H}_{2} \mathrm{~S}$ treatment respectively. However, because of decline in MDA content for control and ethylene treatment at later stage of storage, the content in $\mathrm{H}_{2} \mathrm{~S}$ and ethylene $+\mathrm{H}_{2} \mathrm{~S}$ treatment was significantly higher than that of control or ethylene group.

Effects of ethylene and $\mathrm{H}_{2} \mathrm{~S}$, alone and in combination, on the activities of CAT, APX, $P O D, L O X$, and PPO. Then, the changes in
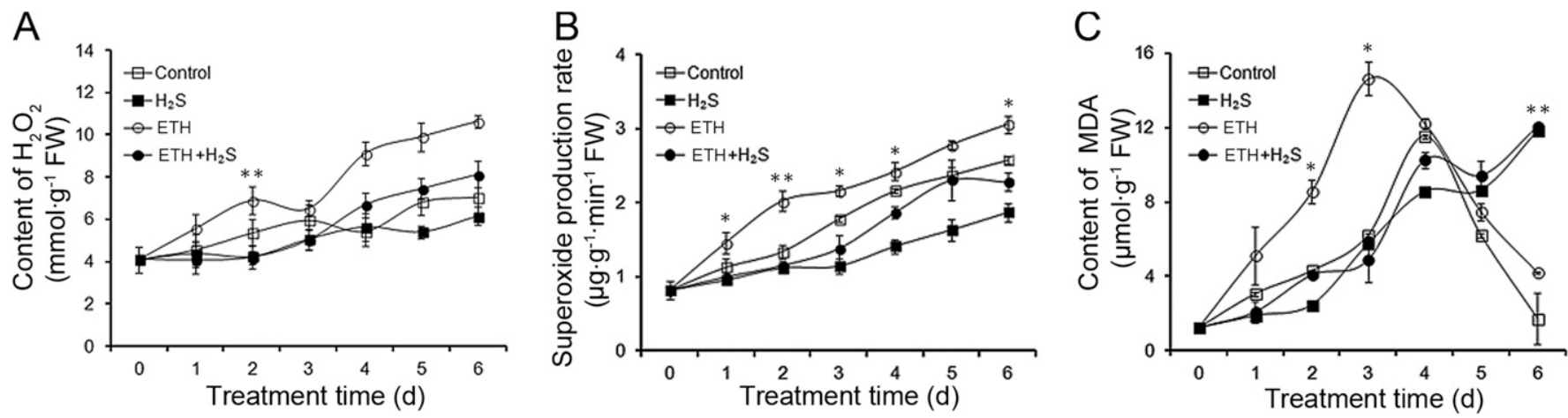

Fig. 4. Changes in oxidative stress of kiwifruit during storage. The content of hydrogen peroxide $\left(\mathrm{H}_{2} \mathrm{O}_{2}\right)(\mathbf{A})$, production of superoxide anion $\left(. \mathrm{O}_{2}{ }^{-}\right)(\mathbf{B})$ and content of malondialdehyde (MDA) (C) were determined on Days 0 to 6 in kiwifruit treated with water, ethylene, $\mathrm{H}_{2} \mathrm{~S}$, or in combination at $25^{\circ} \mathrm{C}$. Control: $\mathrm{H}_{2} \mathrm{O}$; $\mathrm{H}_{2} \mathrm{~S}: 1 \mathrm{~mm} \mathrm{NaHS}$; ETH: $0.4 \mathrm{~g} \cdot \mathrm{L}^{-1}$ ethephon solution; ETH $+\mathrm{H}_{2} \mathrm{~S}: 0.4 \mathrm{~g} \cdot \mathrm{L}^{-1}$ ethephon solution plus $1 \mathrm{~mm}$ NaHS. Data are presented as means \pm standard deviation $(n=3)$. The symbols * and ${ }^{* *}$ stand for significant difference between ETH and ETH $+\mathrm{H}_{2} \mathrm{~S}$ at $P<0.05$ and $P<0.01$, respectively.
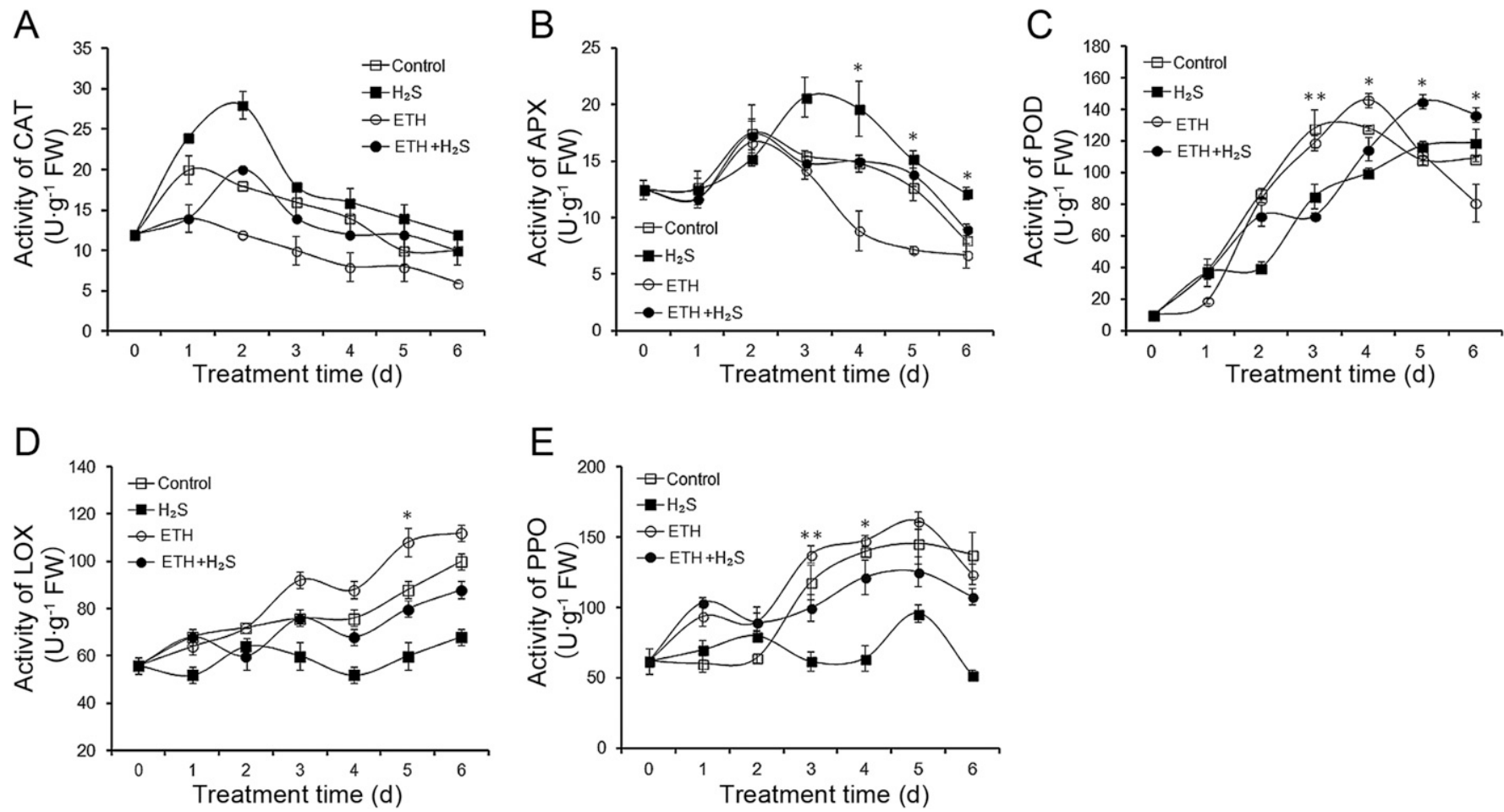

Fig. 5. Effects of ethylene, $\mathrm{H}_{2} \mathrm{~S}$, and combined treatment on the activities of catalase (CAT) (A), ascorbate peroxidase (APX) (B), guaiacol peroxidase (POD) $(\mathbf{C})$, lipoxygenase $(\mathrm{LOX})(\mathbf{D})$, and polyphenol oxidase $(\mathrm{PPO})(\mathbf{E})$ in kiwifruit. The activities were determined daily on Days 0 to 6 in kiwifruit treated with water, ethylene, $\mathrm{H}_{2} \mathrm{~S}$, or in combination at $25^{\circ} \mathrm{C}$. Control: $\mathrm{H}_{2} \mathrm{O} ; \mathrm{H}_{2} \mathrm{~S}$ : $1 \mathrm{~mm} \mathrm{NaHS}$; ETH: $0.4 \mathrm{~g} \cdot \mathrm{L}^{-1}$ ethephon solution; ETH $+\mathrm{H}_{2} \mathrm{~S}: 0.4 \mathrm{~g} \cdot \mathrm{L}^{-1}$ ethephon solution plus $1 \mathrm{~mm}$ NaHS. Data are presented as means \pm standard deviation $(n=3)$. The symbols * and ** stand for significant difference between ETH and ETH $+\mathrm{H}_{2} \mathrm{~S}$ at $P<0.05$ and $P<0.01$, respectively. 
activities of antioxidative enzymes were investigated. As shown in Fig. 5A, the activity of CAT in control sample increased on Day 1 followed by a gradual decrease, whereas $\mathrm{H}_{2} \mathrm{~S}$ treatment alone induced higher CAT activity compared with other groups. The activity was attenuated by ethylene treatment, whereas the combined treatment with $\mathrm{H}_{2} \mathrm{~S}$ induced higher CAT activity after $2 \mathrm{~d}$ of storage.

APX activity in control, ethylene, and ethylene $+\mathrm{H}_{2} \mathrm{~S}$ groups increased and peaked on Day 2 followed by a gradual decrease, whereas the activity in ethylene treatment was significantly lower than other three groups on Days 4 and 5 (Fig. 5B). APX in $\mathrm{H}_{2} \mathrm{~S}$ group increased till Day 3 followed by a decrease, whereas the activity was still significantly higher than control on Days 3 to 5. Activities of POD increased rapidly for all treatments during the first $4 \mathrm{~d}$ of storage followed by a decrease for control and ethylene treatment. POD activity in ethylene treatment was significantly higher than ethylene $+\mathrm{H}_{2} \mathrm{~S}$ on Days 3 to 4 but significantly lower than the combined treatment on Days 5 and 6. Figure 5D showed that LOX activity in $\mathrm{H}_{2} \mathrm{~S}$ treatment fluctuated during storage, whereas that of other three groups increased consistently. However, the rapid increase in LOX activity in ethylene treatment was attenuated in ethylene $+\mathrm{H}_{2} \mathrm{~S}$ after $2 \mathrm{~d}$ of storage. As shown Fig. 5E, a consistent increase in PPO activity was observed in the control, ethylene, and ethylene $+\mathrm{H}_{2} \mathrm{~S}$ except Day 6, whereas the activity in $\mathrm{H}_{2} \mathrm{~S}$ group displayed a fluctuating pattern. Treatments with $\mathrm{H}_{2} \mathrm{~S}$ and ethylene $+\mathrm{H}_{2} \mathrm{~S}$ inhibited the increase in PPO compared with the control or ethylene treatment after $3 \mathrm{~d}$ of storage.

Effects of $\mathrm{H}_{2} \mathrm{~S}$ on expression of genes involved in ethylene synthesis and protein degradation in kiwifruit. Kiwifruit ripening and senescence are accompanied by ethylene production and protein degradation. To study whether $\mathrm{H}_{2} \mathrm{~S}$ has an effect on ethylene synthesis pathway and protein degradation, expressions of $A d S A M$, ACS genes AdACS1-3 and ACO genes $A d A C O 1-3$, and cysteine protease genes $A d C P 1-6$ were measured on Day 1 and 3 of storage. Gene expression of $A d S A M$ in the control sample increased on Days 1 and 3 compared with Day 0, whereas $\mathrm{H}_{2} \mathrm{~S}$ downregulated the expression (Fig. 6A). Besides, $\mathrm{H}_{2} \mathrm{~S}$ also attenuated the expression of AdACS1 and AdACS2 on Days 1 and 3, respectively, whereas the expression of $A d A C S 3$ was not detected in both control and $\mathrm{H}_{2} \mathrm{~S}$ treatment. $A d A C O 2$ and $A d A C O 3$ were highly expressed in control samples, whereas $\mathrm{H}_{2} \mathrm{~S}$ treatment significantly repressed their expressions on Days 1 and 3. $\mathrm{H}_{2} \mathrm{~S}$ did not show obvious effect on the expression of $A d A C O 1$. The expression of cysteine protease genes $A d C P 1$ and $A d C P 3$ increased during kiwifruit storage, whereas $\mathrm{H}_{2} \mathrm{~S}$ significantly repressed their expressions (Fig. 6B). The expressions of other cysteine protease genes were not significantly changed by $\mathrm{H}_{2} \mathrm{~S}$.

\section{Discussion}

Kiwifruit is highly perishable after postharvest ripening, leading to short storage and shelf life. Flesh firmness is an important characteristic for defining postharvest quality of kiwifruit. In the present work, we found that ethephon at $0.4 \mathrm{~g} \cdot \mathrm{L}^{-1}$ is effective in accelerating peel and flesh softening in kiwifruit, and the combination of $\mathrm{H}_{2} \mathrm{~S}$ alleviated ethylene-induced fruit ripening (Fig. 1). Fruit softening is highly associated with physiological events, such as release of galactose from pectic polymers catalyzed by $\mathrm{PG}$ and starch hydrolysis catalyzed by amylase (Gao et al., 2013; Hu et al., 2012). Consistently, increased PG and amylase activities are observed in both control and ethylene treatment, whereas $\mathrm{H}_{2} \mathrm{~S}$ significantly alleviated the increase (Fig. 2). Proteases, which were initially considered to be purely degradative enzymes involved in intracellular protein turnover, are shown to participate in the regulation of many critical physiological and cellular processes (Ehrmann and Clausen, 2004). A recent work found that a number of cysteine protease genes increase their expression during tomato (Solanum lycopersicum) fruit ripening, suggesting the role of protein degradation in fruit ripening (Wang et al., 2017). In our work, $\mathrm{H}_{2} \mathrm{~S}$ significantly repressed the expression of cysteine protease genes $A d C P 1$ and $A d C P 3$, suggesting the alleviated protein degradation in $\mathrm{H}_{2} \mathrm{~S}$-treated fruit (Fig. 6B).

Fruit ripening and senescence are a complex process associated with physiological and biochemical changes. The contents of several functional or antioxidant components, including chlorophyll, carotenoid, ascorbic acid, soluble protein, and reducing sugar, are determined. During postharvest storage, we observed an obvious decrease in ascorbic acid, soluble protein, and reducing sugar in ethylene treatment, whereas combined treatment with $\mathrm{H}_{2} \mathrm{~S}$ could alleviate such a decrease (Fig. 3). During kiwifruit storage, chlorophyll and carotenoid increased continuously in ethylene treatment, but $\mathrm{H}_{2} \mathrm{~S}$ tended to inhibit the increase. Consistent to previous report that ethephon treatment decreased TA value in kiwifruit (Zhang et al., 2012), descending TA value was also observed in ethylene treatment during kiwifruit storage (Fig. 3F). However, $\mathrm{H}_{2} \mathrm{~S}$ or ethylene + $\mathrm{H}_{2} \mathrm{~S}$ sustained higher TA value compared with ethylene treatment.

Fruit ripening and senescence are highly related to the overproduction of superoxide anion $\left(\cdot \mathrm{O}_{2}^{-}\right)$and $\mathrm{H}_{2} \mathrm{O}_{2}$ (Tian et al., 2013). With fruit ripening and senescence, ethylene induced higher levels of $\mathrm{H}_{2} \mathrm{O}_{2}$ and. $\mathrm{O}_{2}{ }^{-}$ compared with control, whereas ROS accumulation was attenuated in ethylene $+\mathrm{H}_{2} \mathrm{~S}$ treatment (Fig. 4A and B). Augmented level of ROS induces oxidative stress, but plants have an efficient enzymatic system and a number of low-molecular-mass antioxidants for detoxification of these oxygen radicals. Antioxidant enzymes CAT, APX, and $\mathrm{POD}$ are required for $\mathrm{H}_{2} \mathrm{O}_{2}$ decomposing
A
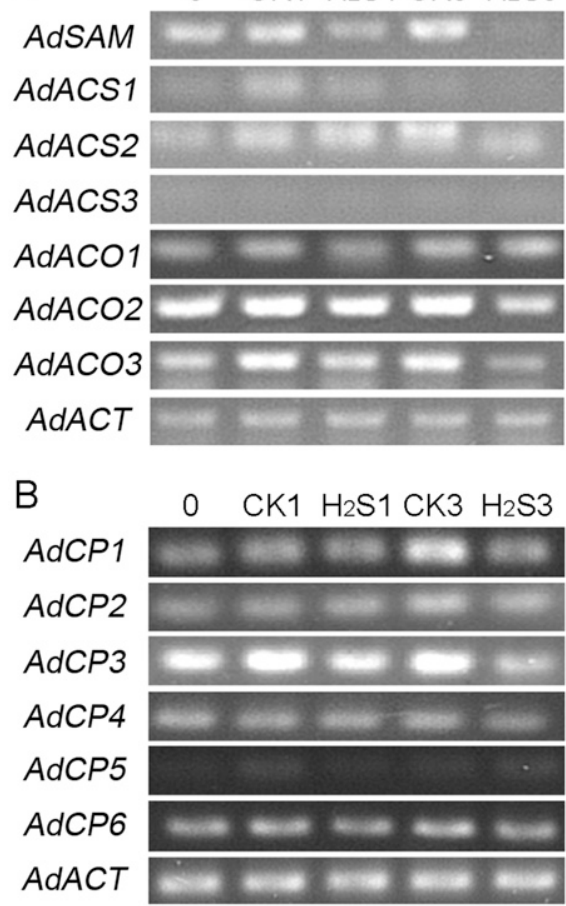

Fig. 6. Effects of $\mathrm{H}_{2} \mathrm{~S}$ on relative expression of ethylene biosynthesis genes (A) and protein degradation related genes (B). The expression of $A d A C T$ gene was used as a control. Ethylene pathway genes, including S-adenosyl methionine synthetase (AdSAM), 1-aminocyclopropane-1-carboxylic acid (ACC) synthase genes (AdACS1, $A d A C S 2$, and $A d A C S 3), \mathrm{ACC}$ oxidase genes ( $A d A C O 1, A d A C O 2$, and $A d A C O 3$ ), and cysteine protease genes $A d C P 1-6$ were assayed on Days 0,1 , and 3 in postharvest kiwifruit subjected to water or $1 \mathrm{~mm} \mathrm{NaHS}$ treatment at $25{ }^{\circ} \mathrm{C}$. CK: water control; $\mathrm{H}_{2} \mathrm{~S}$ : $1 \mathrm{~mm} \mathrm{NaHS}$.

to water and thus constitute the primary antioxidant defense (Gill and Tuteja, 2010). In the present study, ethylene $+\mathrm{H}_{2} \mathrm{~S}$ enhanced the activities of CAT and APX compared with ethylene alone (Fig. 5A and B). Besides, an increased level of ascorbic acid also helped to scavenge $\mathrm{H}_{2} \mathrm{O}_{2}$ in ethylene $+\mathrm{H}_{2} \mathrm{~S}$ treatment (Fig. 3E). Lipid peroxidation mediated mainly by LOXs is involved in fruit ripening and senescence, and LOXs are of a large family of plant enzymes that catalyze the hydroperoxidation of polyunsaturated fatty acids and lead to the production of MDA (Havir and McHale, 1987). In our study, ethylene induced MDA accumulation in the first $4 \mathrm{~d}$ of storage, whereas ethylene $+\mathrm{H}_{2} \mathrm{~S}$ sustained lower levels of MDA and LOX activity, suggesting that lipid peroxidation stress in postharvest kiwifruit was alleviated by $\mathrm{H}_{2} \mathrm{~S}$ (Figs. 4C and 5D). Besides, the activity of PPO, responsible for the enzymatic browning of fruit by catalyzing polyphenols to quinines (Tomás-Barberán and Espín, 2001), was inhibited by $\mathrm{H}_{2} \mathrm{~S}$ treatment (Fig. 5E). These observations suggest that $\mathrm{H}_{2} \mathrm{~S}$ delayed fruit ripening and senescence by inhibiting the accumulation of ROS and alleviating oxidative stress in postharvest kiwifruit. 
Ethylene plays an important role in climacteric fruit ripening and senescence. In the present work we found that $\mathrm{H}_{2} \mathrm{~S}$ repressed the expression of ethylene synthesis related genes AdSAM, AdACS1, AdACS2, AdACO2, and $A d A C O 3$ compared with control. In consistent, $\mathrm{H}_{2} \mathrm{~S}$ was found to downregulate the expressions of $B O A C S 2$ and $B o A C S 3$ in broccoli (Li et al., 2015). A recent work also provides evidence that $\mathrm{H}_{2} \mathrm{~S}$ delays senescence of green leafy vegetable, pak choy (Brassica rapa subsp. Chinensis), by inhibiting both the production of ethylene and the action of ethylene (Al Ubeed et al., 2017).

In conclusion, our results indicated that $\mathrm{H}_{2} \mathrm{~S}$ could alleviate postharvest ripening and senescence of kiwifruit and maintain high fruit quality by decreasing ROS accumulation, improving natural antioxidant contents, and reducing lipid peroxidation. Besides, we provided strong evidence that $\mathrm{H}_{2} \mathrm{~S}$ may play an antagonizing role in the pathway of ethylene by inhibiting the expression of ethylene biosynthesis genes.

\section{Literature Cited}

Adams, D.O. and S.F. Yang. 1979. Ethylene biosynthesis: Identification of 1-aminocyclopropane1-carboxylic acid as an intermediate in the conversion of methionine to ethylene. Proc. Natl. Acad. Sci. USA 76:170-174.

Al Ubeed, H.M.S., R.B.H. Wills, M.C. Bowyer, Q.V. Vuong, and J.B. Golding. 2017. Interaction of exogenous hydrogen sulphide and ethylene on senescence of green leafy vegetables. Postharvest Biol. Technol. 133:81-87.

Association of Official Analytical Chemists (AOAC). 1984. Vitamin C (Ascorbic Acid) in vitamin preparations and juices: 2, 6-dichloroindophenol titrimetric method. 844-845.

Apel, K. and H. Hirt. 2004. Reactive oxygen species: Metabolism, oxidative stress, and signal transduction. Annu. Rev. Plant Biol. 55:373399.

Benjamin, N.D. and M.W. Montgomery. 1973. Polyphenol oxidase of Royal Ann cherries: Purification and characterization. J. Food Sci. 38:799-806.

Bradford, M.M. 1976. A rapid and sensitive method for the quantitation of microgram quantities of protein utilizing the principle of proteindye binding. Anal. Biochem. 72:248-254.

Canan, İ., M. Gündoğdu, U. Seday, C.A. Oluk, Z. Karaşahin, E.Ç. Eroğlu, E. Yazici, and M. Ünlü. 2016. Determination of antioxidant, total phenolic, total carotenoid, lycopene, ascorbic acid, and sugar contents of Citrus species and mandarin hybrids. Turk. J. Agr. For. 40:894899.

Celik, A., S. Ercisli, and N. Turgut. 2007. Some physical, pomological and nutritional properties of kiwifruit cv. Hayward. Intl. J. Food Sci. Nutr. 58:411-418.

Collins, G.G., C.F. Jenner, and L.G. Paleg. 1972. The metabolism of soluble nucleotides in wheat aleurone layers treated with gibberellic acid. Plant Physiol. 49:404-410.

Du, G., M. Li, F. Ma, and D. Liang. 2009. Antioxidant capacity and the relationship with polyphenol and Vitamin C in Actinidia fruits. Food Chem. 113:557-562.

Ehrmann, M. and T. Clausen. 2004. Proteolysis as a regulatory mechanism. Annu. Rev. Genet. 38:709-724.
Elstner, E.F. and A. Heupel. 1976. Inhibition of nitrite formation from hydroxylammoniumchloride: A simple assay for superoxide dismutase. Anal. Biochem. 70:616-620.

Ercisli, S. 2009. Apricot culture in Turkey. Sci. Res. Essays 4:715-719.

Gao, S.P., K.D. Hu, L.Y. Hu, Y.H. Li, Y. Han, H.L. Wang, K. Lv, Y.S. Liu, and H. Zhang. 2013. Hydrogen sulfide delays postharvest senescence and plays an antioxidative role in freshcut kiwifruit. HortScience 48:1385-1392.

García-Mata, C. and L. Lamattina. 2010. Hydrogen sulphide, a novel gasotransmitter involved in guard cell signalling. New Phytol. 188:977984.

Gill, S.S. and N. Tuteja. 2010. Reactive oxygen species and antioxidant machinery in abiotic stress tolerance in crop plants. Plant Physiol. Biochem. 48:909-930.

Harman, J.E. and B. McDonald. 1989. Controlled atmosphere storage of kiwifruit. Effect on fruit quality and composition. Sci. Hort. 37:303315.

Havir, E.A. and N.A. McHale. 1987. Biochemical and developmental characterization of multiple forms of catalase in tobacco leaves. Plant Physiol. 84:450-455.

Hu, L.Y., S.L. Hu, J. Wu, Y.H. Li, J.L. Zheng, Z.J. Wei, J. Liu, H.L. Wang, Y.S. Liu, and H. Zhang. 2012. Hydrogen sulfide prolongs postharvest shelf life of strawberry and plays an antioxidative role in fruits. J. Agr. Food Chem. 60:8684-8693.

Jin, P., Y. Duan, L. Wang, J. Wang, and Y. Zheng. 2014. Reducing chilling injury of loquat fruit by combined treatment with hot air and methyl jasmonate. Food Bioprocess Technol. 7:22592266.

Jin, Z., S. Xue, Y. Luo, B. Tian, H. Fang, H. Li, and Y. Pei. 2013. Hydrogen sulfide interacting with abscisic acid in stomatal regulation responses to drought stress in Arabidopsis. Plant Physiol. Biochem. 62:41-46.

Korsak, T. and Y.S. Park. 2010. Ethylene metabolism and bioactive compounds in ethylenetreated 'Hayward' kiwifruit during ripening. Hort. Environ. Biotechnol. 51:89-94.

Kumar, V., M. Irfan, S. Ghosh, N. Chakraborty, S. Chakraborty, and A. Datta. 2016. Fruit ripening mutants reveal cell metabolism and redox state during ripening. Protoplasma 253:581-594.

Li, D., L. Li, Z. Ge, J. Limwachiranon, Z. Ban, D. Yang, and Z. Luo. 2017. Effects of hydrogen sulfide on yellowing and energy metabolism in broccoli. Postharvest Biol. Technol. 129:136142.

Li, S.P., K.D. Hu, L.Y. Hu, Y.H. Li, A.M. Jiang, F. Xiao, Y. Han, Y.S. Liu, and H. Zhang. 2014 Hydrogen sulfide alleviates postharvest senescence of broccoli by modulating antioxidant defense and senescence-related gene expression. J. Agr. Food Chem. 62:1119-1129.

Li, Z.R., K.D. Hu, F.Q. Zhang, S.P. Li, L.Y. Hu, Y.H. Li, S.H. Wang, and H. Zhang. 2015 Hydrogen sulfide alleviates dark-promoted senescence in postharvest broccoli. HortScience 50:416-420.

Lichtenthaler, H.K. and A.R. Wellburn. 1983. Determinations of total carotenoids and chlorophylls $a$ and $b$ of leaf extracts in different solvents. Biochem. Soc. Trans. 11:591-592.

Miller, G.L. 1959. Use of dinitrosalicylic acid reagent for determination of reducing sugar. Anal. Biochem. 31:426-428.

Mworia, E.G., T. Yoshikawa, N. Yokotani, T. Fukuda, K. Suezawa, K. Ushijima, R. Nakano, and Y. Kubo. 2010. Characterization of ethylene biosynthesis and its regulation during fruit ripening in kiwifruit, Actinidia chinensis 'Sanuki Gold'. Postharvest Biol. Technol. 55:108-113.

Nakano, Y. and K. Asada. 1981. Hydrogen peroxide is scavenged by ascorbate-specific peroxidase in spinach chloroplasts. Plant Cell Physiol. 22:867-880.

Nath, A., B. Bagchi, L.K. Misra, and B.C. Deka. 2011. Changes in post-harvest phytochemical qualities of broccoli florets during ambient and refrigerated storage. Food Chem. 127:1510 1514.

Park, Y.S., S.T. Jung, S.G. Kang, J. Drzewiecki, J. Namiesnik, R. Haruenkit, D. Barasch, S. Trakhtenberg, and S. Gorinstein. 2006. In vitro studies of polyphenols, antioxidants and other dietary indices in kiwifruit (Actinidia deliciosa). Intl. J. Food Sci. Nutr. 57:107-122.

Pathak, N. and G.G. Sanwal. 1998. Multiple forms of polygalacturonase from banana fruits. Phytochemistry 48:249-255.

Sanz, A., C.M. Cortina, and J.L. Guardiola. 1987. The effect of the fruit and exogenous hormones on leaf expansion and composition in citrus. J. Expt. Bot. 38:2033-2042.

Tian, S., G. Qin, and B. Li. 2013. Reactive oxygen species involved in regulating fruit senescence and fungal pathogenicity. Plant Mol. Biol. 82:593-602.

Tomás-Barberán, F.A. and J.C. Espín. 2001. Phenolic compounds and related enzymes as determinants of quality in fruits and vegetables. J. Sci. Food Agr. 81:853-876.

Wang, R. 2012. Physiological implications of hydrogen sulfide: a whiff exploration that blossomed. Physiol. Rev. 92:791-896.

Wang, W., J. Cai, P. Wang, S. Tian, and G. Qin. 2017. Post-transcriptional regulation of fruit ripening and disease resistance in tomato by the vacuolar protease SlVPE3. Genome Biol. $18: 47$.

Yin, X.R., K.S. Chen, A.C. Allan, R.M. Wu, B. Zhang, N. Lallu, and I.B. Ferguson. 2008. Ethylene-induced modulation of genes associated with the ethylene signalling pathway in ripening kiwifruit. J. Expt. Bot. 59:20972108.

Zhang, H., L.Y. Hu, K.D. Hu, Y.D. He, S.H. Wang, and J.P. Luo. 2008. Hydrogen sulfide promotes wheat seed germination and alleviates the oxidative damage against copper stress. J. Integr. Plant Biol. 50:1518-1529.

Zhang, H., S.L. Hu, Z.J. Zhang, L.Y. Hu, C.X. Jiang, Z.J. Wei, J. Liu, H.L. Wang, and S.T. Jiang. 2011. Hydrogen sulfide acts as a regulator of flower senescence in plants. Postharvest Biol. Technol. 60:251-257.

Zhang, H., J. Tang, X.P. Liu, Y. Wang, W. Yu, W.Y. Peng, F. Fang, D.F. Ma, Z.J. Wei, and L.Y. Hu. 2009. Hydrogen sulfide promotes root organogenesis in Ipomoea batatas, Salix matsudana and Glycine max. J. Integr. Plant Biol. 51:1086-1094.

Zhang, L.H., S.F. Li, X.H. Liu, C.L. Song, and X. Liu. 2012. Effects of ethephon on physicochemical and quality properties of kiwifruit during ripening. Postharvest Biol. Technol. 65:69-75.

Zhu, L., W. Wang, J. Shi, W. Zhang, Y. Shen, H. Du, and S. Wu. 2014. Hydrogen sulfide extends the postharvest life and enhances antioxidant activity of kiwifruit during storage. J. Sci. Food Agr. 94:2699-2704

Zorenc, Z., R. Veberic, F. Stampar, D. Koron, and M. Mikulic-Petkovsek. 2016. Changes in berry quality of northern highbush blueberry ( $\mathrm{Vacci}$ nium corymbosum L.) during the harvest season. Turk. J. Agr. For. 40:855-867. 